\title{
УДК:634.8:631.527.2(477) \\ https://doi.org/10.53040/gppb7.2021.55 \\ РЕЗУЛЬТАТЫ СЕЛЕКЦИОННО-ГЕНЕТИЧЕСКИХ И АГРОКЛИМАТИЧЕСКИХ ИССЛЕДОВАНИЙ ВИНОГРАДА В УКРАИНЕ
}

\author{
Ковалева Ирина, Ляменко Галина, Мулюкина Нина \\ Национальный научный центр «Институт виноградарства и виноделия \\ им. B.E. Таирова», Таиров, Украина, е-mail: tairmna2005@ukr.net
}

Мировая селекционная практика убеждает, что стабильную рентабельность и экологичность виноградо-винодельческой отрасли, особенно на лимитированных температурными пределами территориях, может обеспечить принципиально новый сортимент, формирование которого происходит на основе высокопродуктивных сортов сложного межвидового происхождения с высоким качеством урожая.

Сорта винограда нового поколения селекции ННЦ «ИВиВ им. В.Е. Таирова» благодаря синтетической гибридизации и постепенному обогащению генома высококачественных сортов генами устойчивости от Vitis rupestris, Vitis amurensis и др., являются комплексноустойчивыми к биотическим и абиотическим факторам - грибным болезням винограда (милдью, оидиум, гнили), морозу и засухе. Так, оценка устойчивости новых технических сортов к возбудителям болезней грибной этиологии по 9-ти балльной шкале показала устойчивость на уровне 7 баллов у сорта Одесский жемчуг, 7,3 балла - у сорта Ярило и т.д.

Система защиты указанных сортов позволяет уменьшать кратность обработок; если по общепринятой системе защиты виноградных насаждений предлагается проводить от 3 до 5 обработок, то для насаждений устойчивых сортов - всего 1 - 2 обработки против возбудителей грибных болезней винограда, что соответственно позволяет уменьшить пестицидную нагрузку на ампелоценоз с получением экологически чистой продукции и, как результат, положительно влияет на окружающую среду и организм человека.

Анализируя происхождение новых технических сортов селекции ННЦ «ИВиВ им. В.Е, Таирова» и принимая во внимание данные открытой базы данных VIVC о наличии и происхождении генов устойчивости в геноме устойчивых сортов и гибридов - прямых производителей, можно ожидать, что в геномах новых сортов присутствуют определенные гены устойчивости, среди них, например, Rpv3 который определен в прародительских формах Seyve Villard 12-129 и Zeibel-6468. Запланированный на 2022 - 2023 годы совместный проект с селекционерами Турции (Текирдаг) позволит получить ответ на этот вопрос. Молекулярно-генетическая оценка наличия R-генов в новых сортах и формах позволит оценить потенциал их резистентности в системе устойчивого виноградарства и перейти к целевому комбинированию генов устойчивости к милдью и оидиуму в генотипах следующего поколения.

Для детальной оценки потенциала сорта необходима также комплексная оценка ампелоэкологических условий территории. Она включает, в частности, анализ агроклиматических условий на региональном и локальном уровнях, Полученная информация позволит выполнить анализ и оценку рисков повреждения различных сортов винограда в зимний период и в период заморозкоопасности; моделирование формирования производительности винограда по агроклиматическими условиями; тенденцию изменения производительности различных сортов винограда и рисков повреждения сортов винограда по разным сценариям изменения климата до 2050 года. Полученные результаты являются основой для принятия решений применительно к развитию виноградарства в Украине с обоснованием возможной по агроклиматическим ресурсам урожайности различных сортов винограда. 